\title{
Quality Standards for Allergen Immunotherapy Clinics in Spain: Consensus Document
}

Tabar $\mathrm{Al}^{1}$, Núñez Acevedo B2${ }^{2}$, Beitia Mazuecos $\mathrm{JM}^{3}$, Fernández lbáñez $\mathrm{E}^{4}$, Garde Garde J ${ }^{5}$, Hernández Fernández de Rojas $\mathrm{D}^{6}$, De Luque Piñana $\mathrm{V}^{7}$, Ojeda Fernández $\mathrm{P}^{8}$, Reaño Martos $\mathrm{M}^{9}$, Rodríguez Fernández $\mathrm{F}^{10}$, Roger Reig $\mathrm{A}^{11}$, Andrés Martínez J'2, Moreno Aguilar $\mathrm{C}^{13}$, Vidal $\mathrm{C}^{14}$

\author{
'Allergy Department, Complejo Hospitalario de Navarra, Pamplona, Spain \\ ${ }^{2}$ Allergy Department, Hospital Infanta Sofia Madrid, Madrid, Spain \\ ${ }^{3}$ Hospital Universitario de Guadalajara, Guadalajara, Spain \\ ${ }^{4}$ Allergy Department, Hospital Universitario de Alava, Álava, Spain \\ ${ }^{5}$ Hospital General Universitario de Elche, Alicante, Spain \\ ${ }^{6}$ Allergy Department, Hospital Universitario La Fe, Valencia, Spain \\ ${ }^{7}$ Hospital Universitario Virgen Macarena, Sevilla, Spain \\ ${ }^{8}$ Director, Clínica Ojeda, Madrid, Spain \\ ${ }^{9}$ Hospital Universitario Puerta de Hierro, Madrid, Spain \\ ${ }^{10}$ Hospital Universitario Marqués de Valdecilla, Santander, Spain \\ ${ }^{11}$ Allergy Unit, Hospital Universitari Germans Trias i Pujol de Badalona, Barcelona, Spain \\ ${ }^{12} \mathrm{GOC}$ Networking, Barcelona, Spain \\ ${ }^{13}$ Allergy Clinical Management Unit, Hospital Universitario Reina Sofia, Córdoba, Spain \\ ${ }^{14}$ Allergy Department, Complejo Hospitalario Universitario de Santiago, Santiago de Compostela, Spain
}

J Investig Allergol Clin Immunol 2019; Vol. 29(4): 272-279

doi: 10.18176/jiaci.0318

\begin{abstract}
Background: Allergen immunotherapy clinics (AITCS) in Spain differ widely in terms of structure, organization, resources, and portfolio of services. Therefore, it is essential to unify treatment criteria and define quality standards for the most complex AITCs.

Objective: To establish a series of recommendations that make it possible to guarantee quality and safety in the administration of immunotherapy and define quality standards for the most complex AITCs.

Methods: This project began with an online survey of 65 allergy departments/units throughout Spain in 2013. Next, a 2-phase consensus process was carried out. In the first phase, 10 experts defined and agreed on the standards using the RAND/UCLA Appropriateness method; in the second, the agreements were validated by means of a 2-round Delphi consultation with 84 experts.

Results: Consensus was reached on minimum safety and quality criteria in the administration of allergen immunotherapy, and 2 levels of highly complex AITCs were defined: accredited AITCs and accredited AITCs with excellence. Consensus was also reached on quality standards and accreditation criteria for both levels.

Conclusions: This project is pioneering in terms of its purpose (the definition of quality standards for AITCs) and of the use of structured participation techniques (combination of the RAND/UCLA and Delphi methods). It enabled the design of minimum standards for quality and safety in administering AIT, as well as quality criteria for accreditation of AITCs supported by a broad panel of experts from the Spanish Society of Allergology and Clinical Immunology.
\end{abstract}

Key words: Allergens. Delphi. RAND/UCLA. Immunotherapy. Health care quality assurance.

\section{Resumen}

Antecedentes: Las unidades de inmunoterapia (UIT) en España son muy diferentes en cuanto a estructura, organización, recursos y cartera de servicios. Por ello, resulta esencial homogeneizar criterios de actuación y definir estándares de calidad para las UIT de mayor complejidad. Objetivo: Establecer recomendaciones que permitan garantizar la calidad y seguridad en la administración de la inmunoterapia y definir estándares de calidad para las UIT de mayor complejidad.

Métodos: Proyecto iniciado (año 2013) con una encuesta on-line a 65 servicios o unidades de alergología de toda España. Posteriormente se desarrolló un proceso de consenso en dos fases. En la primera, diez expertos definieron y consensuaron los estándares mediante el método RAND/UCLA; en la segunda, los acuerdos se validaron mediante una consulta Delphi a dos rondas con 84 expertos.

Resultados: Se consensuaron criterios mínimos de seguridad y calidad en la administración de inmunoterapia con alérgenos (ITA) y se definieron dos niveles de UIT de mayor complejidad: las UIT acreditadas (UITA) y las UIT acreditadas con excelencia (UITAE), consensuándose también los estándares de calidad y criterios de acreditación para ambos niveles. 
Conclusiones: Proyecto pionero en su objetivo - definición de estándares de calidad de UIT-y en el empleo de técnicas de participación estructuradas -combinación de los métodos RAND/UCLA y Delphi-. El resultado es la definición de unos mínimos de calidad y seguridad para administrar ITA, y un conjunto de criterios de calidad para la acreditación de las UIT que cuenta con el respaldo de un amplio panel de expertos de la SEAIC.

Palabras clave: Alérgenos. Delphi. RAND/UCLA. Inmunoterapia. Calidad asistencial.

\section{Introduction}

Allergen immunotherapy (AIT) is aimed at modifying the clinical-immunological response of individuals with IgEmediated allergies. It is based on the controlled administration of pharmacological products in which the active ingredient is the allergen responsible for the disease. Thus, in order to ensure its safety and obtain maximum therapeutic efficacy, it is essential to monitor patients in allergen immunotherapy clinics (AITCs) that guarantee certain quality standards [1-4].

AITCs are staffed by professionals with expertise in the administration of allergen extracts. They are located within health care centers that have sufficient resources and access to an allergy specialist [3,5]. AITCs in Spain are numerous and very different, and their structure reflects the capacities of their organizers and the resources of each health care environment. Likewise, the portfolio of AITC services differs widely, as some clinics administer AIT for patient treatment purposes, others have research facilities, and others offer training. Accordingly, given the absence of a normative framework for authorizing the opening and/or operation of AITCs, it is essential to define a series of standards in order to guarantee the quality and safety of the treatment administered to patients in these units. Allergy specialists from the Spanish Society of Allergology and Clinical Immunology (SEAIC) and its AIT Committee agreed to implement a formal consensus process.

The objectives of this process were as follows: $(a)$ to define minimum criteria and requirements to serve government agencies, clinic operators (public or private), and physicians and nursing staff who work in the allergy field and are involved in the administration of AIT, with the aim of guaranteeing safe conditions, quality, and patient rights in the AITCs; $(b)$ to define minimum recommendations that allow operational criteria to be established and guarantee safety in the administration of the treatment; $(c)$ to define a series of quality standards for high-complexity AITCs, with the final objective of establishing operational criteria at the treatment level, so that they can be accredited by the SEAIC in the future; and $(d)$ to establish general recommendations relating to the organization, management, physical structure, and resources of AITCs.

\section{Methods}

This study was carried out based on data from 153 allergy departments/units located throughout Spain. Data were obtained by means of an online survey conducted by the SEAIC AIT Committee in 2013. The purpose was to obtain a map of the situation of the AITCs in the country at that time. The results of the analysis led us to design a 2-phase consensus process:

Phase 1. This involved application of the RAND/ UCLA method, the results of which are based on available scientific evidence and expert opinion. The participants comprised 10 allergy specialists with specific expert profiles (quality, management, and care management), led by a group of 4 coordinators.

A 2-phase literature search was conducted. This involved an initial search for possible pre-existing criteria and sources concerned mainly with care quality and management, and a second, more specific search based on a nonexhaustive systematic review of the literature. This second review was conducted in Medline in Spanish and English and was limited to publications from the last 5 years: this was extended to 10 years if no relevant results were found. Likewise, clinical practice guidelines, reviews, consensus documents, care protocols, and recommendations were prioritized.

Based on the selected publications, a quality standards proposal was developed and evaluated by all the experts on an individual basis in an online validation round. Four response options were defined for each proposal, with 1 being "strongly disagree" and 4 being "strongly agree". For the analysis, the results of 1 and 2 were grouped together as "disagree" and 3 and 4 as "agree". The criteria for accepting or rejecting a standard were established based on the combined "agree" options (3 and 4) and defined as follows: unanimity (100\% agreement), consensus ( $\geq 85 \%$ agreement), variance (agreement between $66 \%$ and $84 \%$ ), and rejection (agreement $<66 \%$ ). The standards that were classified as variance or rejection were sent back to the experts for a second round of individual assessment. Lastly, a group validation session was held to discuss the proposals for which consensus had not been achieved in either of the 2 rounds.

Phase 2. For the purpose of extending the agreements to a larger group of experts, a consultation based on the Delphi method was conducted in 2 rounds. To do so, a group was formed comprising 5 advisors who had collaborated in the preparation and validation of the surveys, participated in the methodological decisions, and advised on the analysis and interpretation of the results. The panelists were selected based on their experience in the subject matter of the consultation. In the selection process, previous agreement by another expert from the same center to participate in the consultation was a potential exclusion criterion.

The survey used a Likert scale of 5 response options, where 1 was "strongly disagree" and 5 was "strongly agree". For the analysis, 1 and 2 were grouped together as "disagree" 
and 4 and 5 as "agree". The criteria for accepting or rejecting a standard were established based on the combined "agree" options (3 and 4) and were defined as follows: consensus ( $\geq 90 \%$ agreement), majority (agreement between $66 \%$ and $89 \%$ ), and discrepancy (agreement $<66 \%$ ).

Phases 1 and 2 were conducted between December 2014 and January 2017, with methodological support from the GOC Networking consultancy team.

\section{Results}

\section{Survey Prior to Consensus}

Of the 153 departments/units to which the survey was sent, a total of $65(42.5 \%)$ responded. The data obtained provided a preliminary census and a map of the situation of the AITCs in terms of human resources, allergen extracts and guidelines followed, records used, teaching and research activity, type of patients treated, and communication with primary care. Nonetheless, identification of the considerable structural and functional variability of the AITCs surveyed justified the consensus process, the results of which are shown below.

\section{Literature Search of the Consensus Process in Phase 1}

The nonexhaustive and systematic literature search yielded 1164 publications, of which 42 were prioritized based on topicality, theme, relevance, and quality of the scientific publication. Another 62 publications were added to these 42 , based on a targeted search for topics related to care quality and management.

\section{Experts Participating in Phase 2}

A total of 237 experts were invited to participate in phase 2 (2-round consultation): of these, 93 (39.2\%) agreed to participate and responded in the first round, and 84 (90.3\% of the first round respondents) responded in the second round.

\section{Consensus Process (Phases 1 and 2)}

The criteria and indicators shown below are those proposed by the group of experts in the RAND/UCLA process (phase 2). Agreement by the panel of experts that participated in the Delphi consultation (phase 2) was $\geq 90 \%$.

\section{Minimum Safety and Quality Criteria}

The administration of medication (particularly allergen extracts) carries a risk of triggering adverse, mainly allergic reactions that can prove life-threatening if the necessary care is not provided. Accordingly, AITCs should be equipped and organized to guarantee patient safety, prevent risks, and properly treat adverse reactions. For this reason, it is essential that all AITCs administering AIT apply the minimum safety and quality criteria (Table).

\section{Quality Criteria for Accreditation of AITCS}

The main purpose of the accreditation system for AITCs is to have a set of standards that define the minimum criteria required for units of similar complexity in order to guarantee optimal quality of care, promote research in immunotherapy, and establish a continuous improvement model in all AITCs. Thus, the criteria shown below were prepared with a view to potentially accrediting AITCs with a seal of excellence. Nonetheless, any AITC that wishes to attain accreditation must meet the mandatory minimum safety/ quality criteria for the administration of AIT; if the AITC opts for accreditation with the seal of excellence, it must also satisfy the criteria of the accredited AITCs (AITCAs). These criteria are human resources, specific physical spaces, specific technical resources, portfolio of services, standard operating procedures (SOPs), care activity, and training. The criteria that an AITCA must meet are outlined for each block (Table).

Lastly, the requirements that AITCs accredited with excellence (AITCAEs) must meet are defined. These must satisfy all of the previous specifications (the minimum and those required of an AITCA) and those indicated in the Table, which are grouped by type.

\section{Discussion}

Our definition of a set of quality standards and the corresponding accreditation system for types of centers and treatment resources is not new. There are at least 2 significant forerunners in Spain: the Top 20 programme, promoted by IASIST [6], and the accreditation based on ISO 9001 standards obtained by the Centro de Atención Primaria de la Vila Olímpica (Barcelona) in 2002. Also noteworthy at international level is the model promoted by the Joint Commission in the United States since the early 1980s, which is based on a series of specific and differentiated indicators for each care center [7].

The review of the scientific literature conducted during the first phase of this consensus process enabled the identification of various clinical practise guidelines, both in Europe and in Spain. These guidelines proposed norms and standards for assuring quality and safety for certain diseases and for potential complications of some services provided by AITCs [8-11]. Nevertheless, none of the references found presented a global accreditation model for AITCs to administer the various types of AIT. Although the systematic literature review was not exhaustive and only 1 database was examined, our initiative can be considered pioneering. In addition, it is based on available scientific evidence and the opinion of a wide group of experts and established the most important criteria for patient safety and service quality in the AITC as regards human resources, physical spaces and technical resources, portfolio of services, SOPs, relationship between AITCs and primary care, continuous education, teaching, and research.

In order to gradually increase quality and safety in AITCs in Spain, the next step in this ambitious project is for the SEAIC to accredit Spanish AITCs until it completes, in the next 3-4 years, the full plan-do-check-act cycle of continuous improvement in quality of care. To do so, it is essential to define an accreditation standard with the corresponding certification process, expressed in the form of a document that the SEAIC will publish as soon as it has been drafted. 


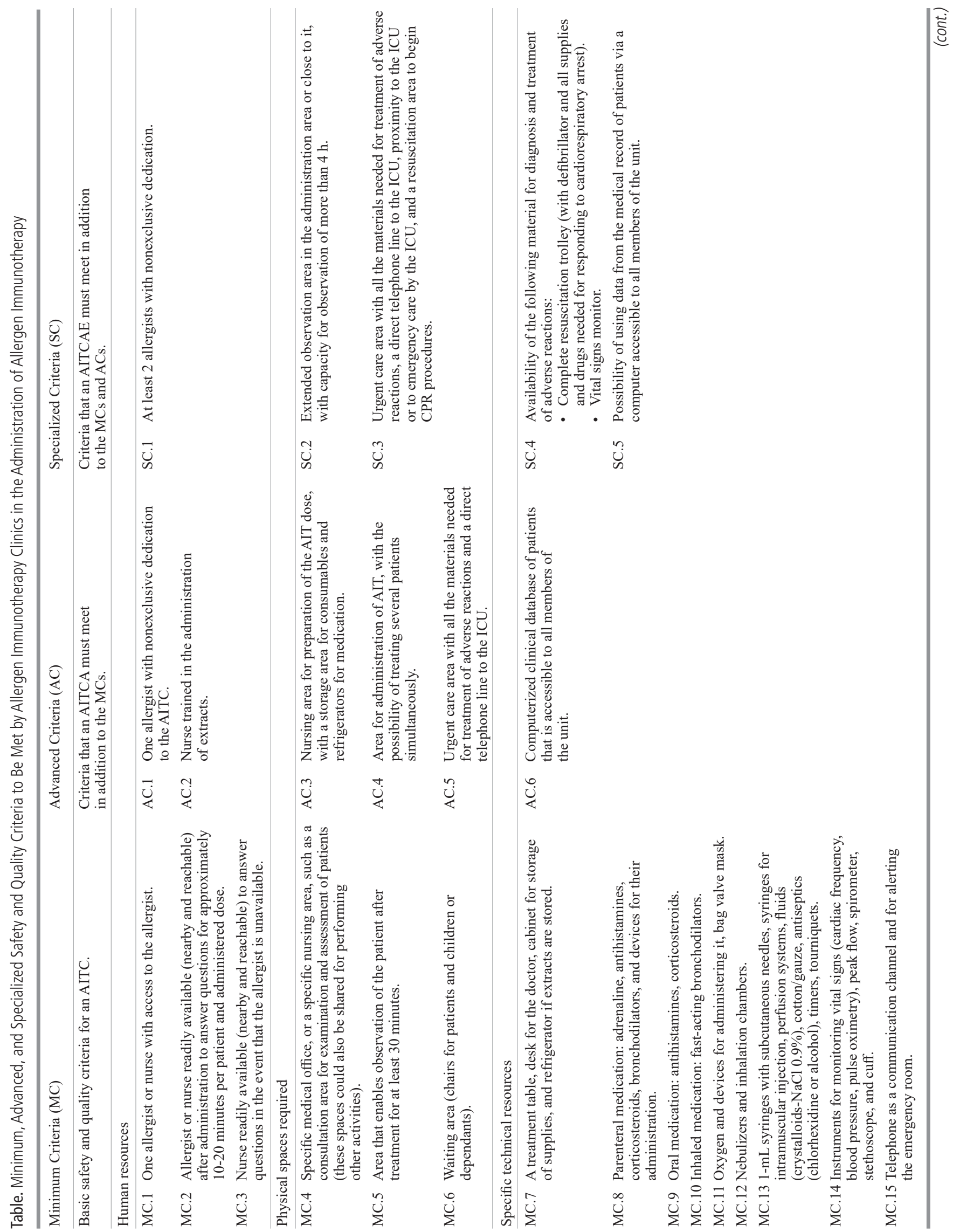




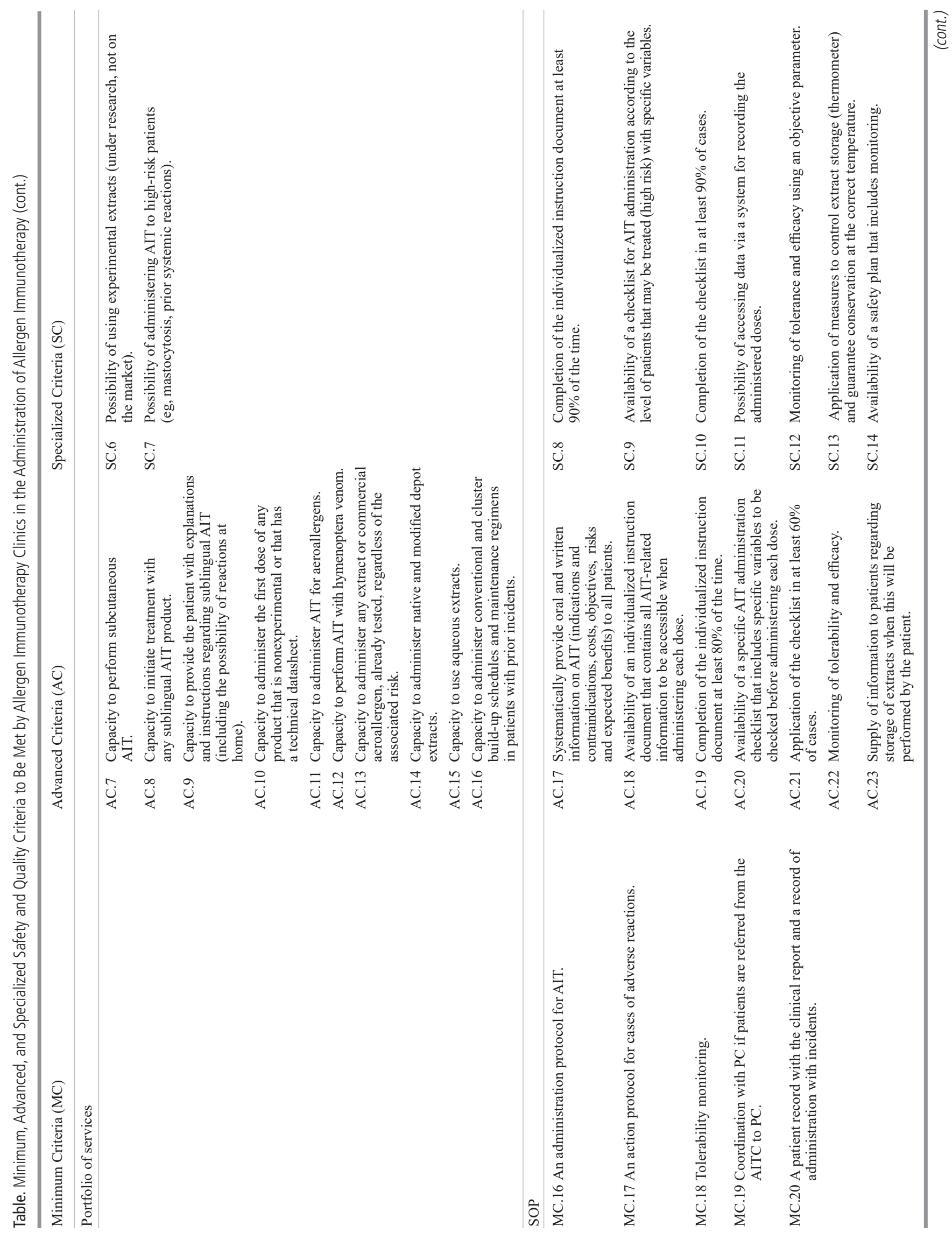




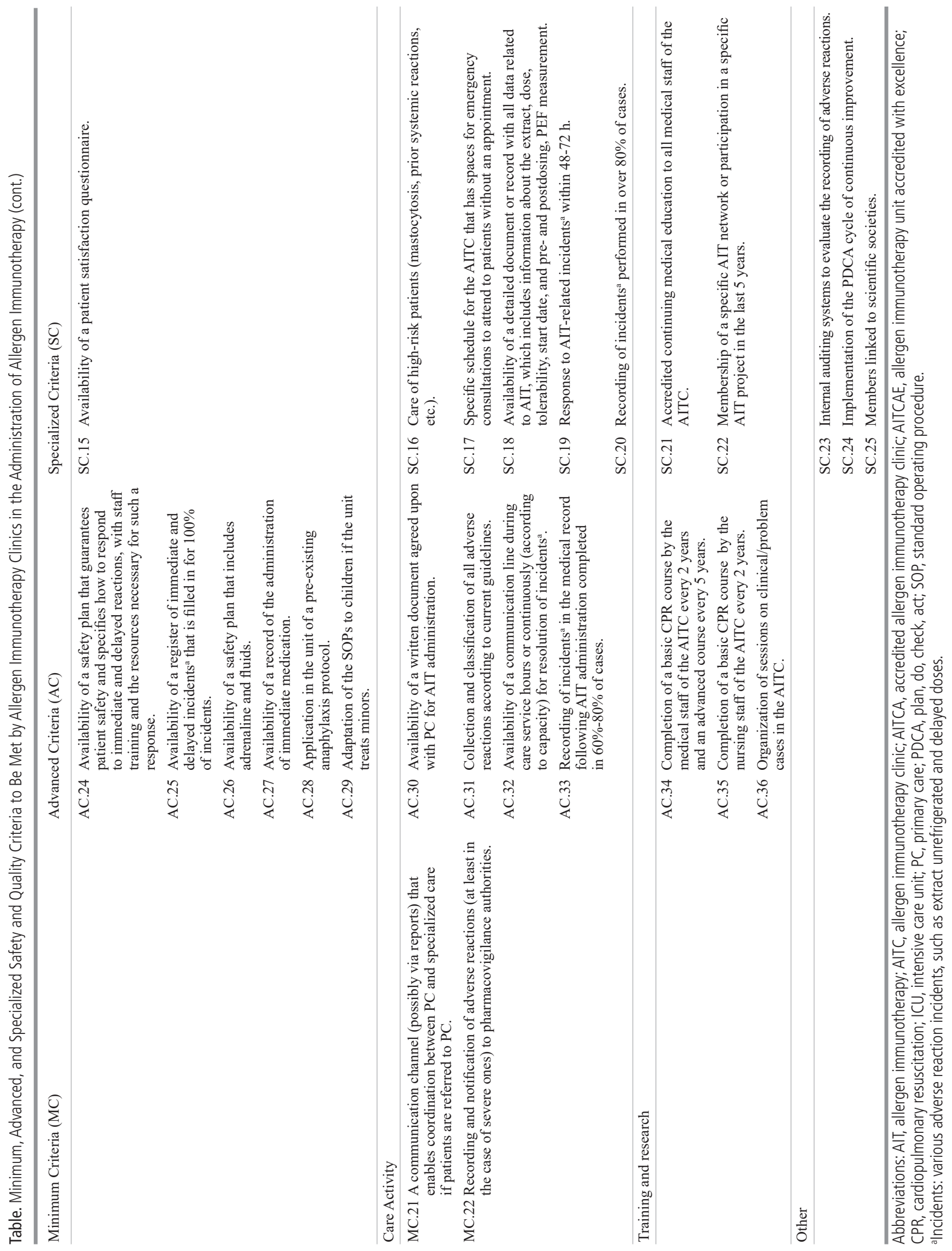




\section{Acknowledgments}

The authors are grateful to the panel of experts who took part in the Delphi phases: Sara Acero Sáinz (Nuestra Señora de Sonsoles, Ávila), Teresa Alfaya Arias (Hospital General Universitario de Ciudad Real, Ciudad Real), Ana Alonso Llamazares (Hospital de Guadalajara, Guadalajara), Manuela Alvarado Arenas (Private Clinic, Cáceres), María Isabel Alvarado Izquierdo (Allergy Clinic, Cáceres), Darío Antolín Amérigo (Hospital Universitario Príncipe de Asturias, Asturias), Mónica Antón Gironés (Hospital Vinalopo Salud de Elche, Alicante), María Ascensión Aranzábal Soto (Hospital de Zumárraga, Guipúzcoa), Alicia Armentia Medina (Hospital Universitario Río Hortega, Valladolid), Ana Beristain Urquiza (Hospital Monte Naranco/Policlínicas Begoña, Asturias), Mariangélica Bermúdez Martínez (Hospital Rey Juan Carlos, Madrid), Nagore Bernedo Belar (Hospital Universitario Araba, Álava), Carlos Blanco Guerra (Hospital Universitario la Princesa, Madrid), Pedro Bobadilla González (Complejo Hospitalario Universitario de Badajoz, Badajoz), María Nieves Cabañes Higuero (Private Clinic, Toledo), Victoria Cardona Dahl (Hospital Universitario de la Vall d'Hebron, Barcelona), Carlos Colás Sanz (Hospital Clínico Universitario Lozano Blesa, Zaragoza), Ignacio Dávila González (Hospital Virgen de la Vega, Salamanca), Carlos Hernando de Larramendi Martínez (Hospital Marina Baixa, Villajoyosa, Alicante), Carmen Domínguez Noche (Private Clinic, Cáceres), Javier Domínguez Ortega (Hospital la Paz, Madrid), Teresa Dordal Culla (Hospital Municipal Badalona, Barcelona), Ana Elices Elices (Hospital del Henares, Coslada/ Centro Médico, Arganda del Rey, Madrid), Ernesto Enrique Miranda (Hospital de Sagunto, Valencia), Alicia Enríquez Matas (Hospital 12 de Octubre, Madrid), Montserrat Fernández Rivas (Hospital Clínico San Carlos, Madrid), Consuelo Fernández Rodríguez (Hospital 12 de Octubre, Madrid), Pere Gaig Jané (Hospital Universitario Joan XXIII, Tarragona), Ignacio García Núñez (Hospital Quirón Campo de Gibraltar, Córdoba), José Carlos García Robaina (Hospital Universitario Nuestra Señora de la Candelaria/ Private Clinic, Santa Cruz de Tenerife), Gema García Sánchez (Hospital Sanitas la Moraleja, Madrid), Teresa Garriga Baraut (Hospital Universitario Maternoinfantil de La Vall d'Hebron, Barcelona), Belén Gómez Breñosa (Hospital Reina Sofía, Navarra), Eloina González Mancebo (Hospital de Fuenlabrada, Madrid), Luís Alonso González Sánchez (Hospital General la Mancha Centro, Ciudad Real), María Ángeles Gonzalo Garijo (Hospital Universitario Infanta Cristina, Badajoz), Pedro Guardia Martínez (Hospital Universitario Virgen Macarena, Sevilla), Francisco Javier Hernández Arbeiza (Hospital de Cáceres, Cáceres), Belén Hinojosa Jara (Centro Específico de Especialidades Virgen de la Cinta, Huelva), Macel Ibero Iborra (Hospital de Terrasa, Barcelona), Alfredo Iglesias Cadarso (Hospital Puerta de Hierro, Madrid), Pilar Iriarte Sotes (Complejo Hospitalario Universitario de Ferrol, A Coruña), Ignacio Jauregui Presa (Hospital de Basurto, Vizcaya), Gloria Jiménez Ferrera (Private Clinic Badajoz), Alejandro Joral Badas (Hospital Donostia, Guipúzcoa), Sonsoles Juste Picón (Hospital Universitario de Burgos, Burgos), María Ángeles Lara Jiménez (Hospital Universitario San Cecilio, Granada), Ramón Lleonart Bellfill (Clínica Sant Josep (Manresa)/Hospital Universitari Bellvitge, Barcelona), Teófilo Lobera Labairu (Hospital San Pedro, La Rioja), José Damián López Sánchez
(Hospital Universitario Virgen Arrixaca, Murcia), Carles Lucas Giralt (Sant Pere Claver Fundación Sanitaria, Barcelona), Lluís Marquès Amat (Hospital Universitario Arnau de Vilanova de Lleida, Lérida), Mercedes Martínez San Ireneo (Hospital Virgen del Valle, Toledo), Antonio Martorell Aragonés (Hospital General Universitario - Valencia, Valencia), Gemma Mencía Sánchez (Hospital de la Plana, Villareal, Castellón de la Plana), Jorge Darío Méndez Alcalde (Hospital Río Carrión, Palencia), Juan Carlos Miralles López (Hospital Universitario Reina Sofía, Murcia), Francisco Moreno Benítez (Clínica Doctor Lobatón, Cádiz), María Pilar Muñoz Pamplona (Private Clinic/Hospital Obispo Polanco, Teruel), Pilar Mur Gimeno (Hospital Santa Bárbara, Ciudad Real), Blanca Noguerado Mellado (Hospital Gregorio Marañón, Madrid), Alberto Oehling (Centro de Alergia y Asma Balear, Islas Baleares), Rafael Pamies Espinosa (Hospital Línea de la Concepción, Cádiz), Carmen Panizo Bravo (Hospital Nuestra Señora del Prado, Toledo), Antonio Parra Arrondo (Complejo Hospitalario Universitario A Coruña, A Coruña), Ignacio Pérez Camo (Hospital Royo Villanova/MAZ Zaragoza/Private Clinic, Zaragoza), Dolores Quiñones Estévez (Hospital Monte Naranco, Asturias), Joaquín Quiralte Enríquez (Hospital Universitario Virgen del Rocío, Sevilla), Santiago Quirce Gancedo (Hospital Universitario la Paz, Madrid), Beatriz Rodríguez Jiménez (Hospital Getafe, Madrid), Javier Ruiz Hornillos (Hospital Universitario Infanta Elena, Valdemoro, Madrid), Blanca Sáenz de San Pedro Morera (Complejo Hospitalario de Jaén, Jaén), Cesárea Sánchez Hernández (Complejo Hospitalario Universitario de Huelva, Huelva), Inmaculada Sánchez Machín (Hospital del Tórax/Hospital de Ofra/Private Clinic, Santa Cruz de Tenerife), Leticia Sánchez Morillas (Hospital Clínico San Carlos, Madrid), Irán Sánchez Ramos (Clinica Dermatología y Alergia, Badajoz), Marcela Santaolalla Montoya (Hospital de Madrid Norte San Chinarro, Madrid), Joaquín Sastre Domínguez (Fundación Jiménez Díaz, Madrid), Miguel Ángel Tejedor Alonso (Hospital Fundación Alcorcón, Madrid), María Jesús Trujillo Trujillo (Hospital del Tajo, Aranjuez, Madrid), José María Vega Chicote (Hospital Regional Universitario de Málaga, Málaga), Felicitas Villas Martínez (Hospital Royo Villanova, Zaragoza).

The authors also thank the SEAIC for its support, Stallergenes-Greer for the financial support to carry out the project, and GOC Networking for methodological support.

\section{Funding}

This study was made possible by a grant from StallergenesGreer laboratories.

\section{Conflicts of Interest}

All authors have received funding from Stallergenes-Greer laboratories to cover the logistics of this project when necessary.

- Ana I. Tabar has received speaker and consultant fees from ALK-Abelló S.A., Allergy Therapeutics, LETI, Stallergenes-Greers, Merck S.L., Diater and Inmunotek.

- Beatriz Núñez Acevedo has participated in conferences for Stallergenes-Greer.

- Juan María Beitia Mazuecos has participated in clinical assays from ALK-Abelló S.A. and Diater and has received fees as speaker from Stallergenes-Greer, Allergy Therapeutics, and LETI. 
- Eduardo Fernández Ibáñez has collaborated in clinical trials from ALK-Abelló S.A., Allergy Therapeutics, Merck S.L, Roxall and Diater and has acted as a consultant for Stallergenes-Greer and ALK-Abelló S.A.

- Jesus Garde Garde declares that he has no conflicts of interest.

- Dolores Hernández Fernández de Rojas declares that she has no conflicts of interest.

- Virginia De Luque Piñana has participated in clinical assays from ALK-Abelló S.A., Merck S.L, LETI, and Inmunotek and has collaborated as a speaker with ALKAbelló S.A., Allergy Therapeutics, and LETI.

- Pedro Ojeda Fernández has participated in clinical trials or in scientific collaboration with ALK-Abelló S.A., Allergy Therapeutics, Roxall, Diater, Inmunotek S.L., Probelte Pharma and Stallergenes-Greer.

- Mar Reaño Martos declares that she has no conflicts of interest.

- Fernando Rodríguez Fernández has participated in clinical assays from ALK-Abelló S.A., Allergy Therapeutics, and LETI.

- Albert Roger Reig has participated in clinical trials from Stallergenes-Greer, ALK-Abelló S.A., LETI, Allergy Therapeutics, Merck S.L, Roxall and ALK-Abelló S.A. He has also received speaker fees from Allergy Therapeutics and has participated as consultant for Stallergenes-Greer, LETI, Allergy Therapeutics, Merck S.L., Roxall and Diater.

- Josep Andrés Martínez is employed by GOC Networking, which received consultation fees from StallergenesGreer for this project

- Carmen Moreno Aguilar has participated in clinical trials from ALK-Abelló S.A. and Biotech Tools and has participated as speaker with ALK-Abelló S.A. and Merck S.L.

- Carmen Vidal has participated in clinical assays from Stallergenes-Greer, ALK-Abelló S.A., LETI, and HAL Allergy Group. She has also received speaker fees from ALK-Abelló S.A., Stallergenes-Greer, and Allergy Therapeutics and has participated as consultant for ALKAbelló S.A.

\section{References}

1. Sturm GJ, Varga EM, Roberts $G$, Mosbech $H$, Bilò MB, Akdis $C A$, et al. EAACl guidelines on allergen immunotherapy: hymenoptera venom allergy. Allergy. 2018;73(4):744-64.
2. Moreno C, Gonzalo MA, Sánchez I. Capítulo 23: Seguridad y eficacia en la inmunoterapia. In: SEAIC, editor. Tratado de Alergología. II. 2nd ed 2017.

3. Tabar Al, Serrano P, Beitia JM, Núñez B. Capítulo 24: Tipos de inmunoterapia. In: SEAIC, editor. Tratado de Alergología. II. 2nd ed 2017.

4. de Luque V, Chivato T, Iglesias FJ, Esteso O. Capítulo 25: Manejo práctico de la inmunoterapia. In: SEAIC, editor. Tratado de alergología. III. 2nd ed 2017.

5. Dasilva A. Being prepared for the unexpected. Nursing. 2014;44:8-9.

6. Programa Hospitales TOP 20 [10-19-2017]. Available from: http://www.iasist.com.es/es/1315/Hospitales-TOP-20.

7. Joint Commission International. Acreditation standards for hospitals 2011 [19-10-2017]. Available from: http://www. jcrinc.com/store/publications/.

8. Zuberbier T, Bachert C, Bousquet PJ, Passalacqua G, Walter Canonica $G$, Merk $H$, et al. GA(2) LEN/EAACl pocket guide for allergen-specific immunotherapy for allergic rhinitis and asthma. Allergy. 2010;65:1525-30.

9. Seicap. [Normative documents of the Spanish Society for Pediatric Clinical Immunology and Allergology. Minimum requirements for practicing the specialty of pediatric allergy and immunology in a hospital setting]. Allergol Immunopathol (Madr). 2003;31:192-7.

10. Cardona Dahl V, Grupo de trabajo de la Guia Gdaea. [Guideline for the management of anaphylaxis]. Med Clin (Barc). 2011;136:349-55.

11. Alvarez-Cuesta E, Bousquet J, Canonica G, Durham S, Malling

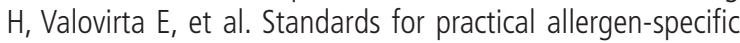
immunotherapy. Allergy. 2006;61 Suppl 82:1-20.

Manuscript received July 23, 2018; accepted for publication September 10, 2018.

\section{Ana I Tabar Purroy}

Allergy Department. Complejo Hospitalario de Navarra. Calle de Irunlarrea, 3 31008 Pamplona, Spain

E-mail: ana.tabar.purroy@cfnavarra.es 